\title{
I Foucaults fodspor
}

\section{AF Bente RosenbeCK}

fik jeg fat i endnu en bog om Foucault: Foucault, the Family and Politics, redigeret af Robbie Duschinsky og Leon Antonio Rocha. Bogen udkom i 2012 og har udgangspunkt i konferencen Foucault, the Family and Politics, der blev afholdt i Cambridge i 2010. To ting slog mig umiddelbart: For det første nævner de to redaktører, at Dit et écrits, som indeholder samtlige Foucaults værker og interviews, ikke har 'familie' som emneord i registreret, og for det andet gør de opmærksom på, at end ikke centrale kapitler i Seksualitetens Historie er blevet set som "a theoretical contribution on the topics of the family" (Duschinsky \& Rocha, 2012: 1).

Da jeg xrgrede mig over ikke at have været opmærksom på denne konference, og da mit første forskningsprojekt, som havde reproduktion og seksualitet som udgangspunkt, blev formuleret med udgangspunkt i Foucaults analyser, tænkte jeg, at dette essay måtte være et 'oplæg i utide'. Her føl- 
ger det 'oplæg', som jeg kunne have holdt på Cambridge konferencen, og hvor jeg parallelt til flere af artiklerne i bogen, skriver om, hvad Foucault har betydet for min forskning.

\section{INSPIRATION FRA FOUCAULT}

Det var mit held, at Seksualitetens historie hurtigt udkom på dansk, nemlig to år efter udgivelsen (1978, org. 1976). Det var Foucaults biopolitik i sidste del af Seksualitetens historie, som blev inspirationskilde. Emner, som hidtil ikke havde haft historikernes interesse: køn, befolkning, reproduktion, seksualitet, blev draget ind i det politiske felt. Biologi og politik blev knyttet sammen, og den politiske historie blev relevant på en ny måde. Politikbegrebet blev udvidet og ikke kun begrænset til det offentlige. Disse emner trak historiefaget $\mathrm{i}$ retning af socialhistorie og kulturhistorie. Jeg lod Foucaults analyser af, hvordan kønnet og det seksuelle blev et verdsligt og statsligt anliggende, udpege de områder, som jeg belyste i min afhandling og senere i bogen Kvindekøn. Den moderne kvindeligheds historie 18801980, som udkom i 1987. Det drejede sig om demografien, der tog sig af befolkningsforhold og fødselsregulering, og medicinen, der tog sig af kvindens krop, pædagogikken af barnets seksualitet og seksualvidenskaben af de perverse. Men jeg var så meget historiker, at jeg ville fastholde en socialhistorisk ramme for analysen af videnskabens produktion af viden, som jeg skrev i Kroppens politik (1992: 89ff). Her opererer jeg med en dobbelt analyse, der kombinerer diskursanalyse og socialkonstruktionsteori med socialhistorie (ibid: 127).

Jeg var nok dengang mest optaget af at synliggøre de magtstrukturer, der havde begrænset kvinders liv, og derfor kan man godt sige, at de konkrete handlende kvinder ikke var i centrum i Kvindekøn. Men det mærkelige var, at selv om jeg gik i Foucaults fodspor, så fik analysen af den medicinske diskurs modstand fra den socialhisto- riske og ikke mindst den demografiske udvikling. Jeg gik til statistik og demografi og ved at bruge andres tal, og her tænker jeg især på P. C. Matthiessens disputats: Some Aspects of the Demographic Transition in Denmark (1970), var det uundgåeligt ikke at se, at der var foregået store forandringer med kroppen og det legemlige. Statistikken skrev næsten af sig selv frem, at der var sket en revolution i kvinders livsforløb. Børnetallet faldt, mødres gennemsnitsalder faldt, antallet af gifte steg, der blev færre børn, men flere blev mødre, altså en demokratisering af moderskabet (Rosenbeck 1987: 50ff). Disse forandringer betød, at kvinder var mindre bundet af børnefødsler, og da de også levede længere, gav det i princippet kvinderne nye muligheder i livet. Dertil kom bedre sundhedstilstand, længere levetid og faldende dødelighed.

Så var der den modsatte tendens: Det diskursive niveau med kroppens videnskabeliggørelse, hvor lægerne udviklede teorien om, at reproduktiviteten blev konstituerende for kvindelighed. Den reproduktive evne kom til at totalisere kvinders liv fra vugge til grav (ibid: 78ff). Det var ret utrolig, hvad videnskaben og lægerne kunne finde på at sige om kvinder. Det var datidens ideologi, som blev ophævet til videnskab. På den ene side skete der en revolutionering af kvinders livscyklus og på den anden side en biologisering og naturalisering af kvindelighed. En biologisk myte eller den reproduktive biologi blev konstrueret. Derfor skulle biologien tilbage til historien, og kvinder skulle befries fra 'naturhistoriens lænker' (ibid: 56).

Da Karin Lützen og jeg skrev "Den moderne tid", som var bind 5 i Det Europaiske Hus redigeret af Søren Mørch (1991), var begejstringen for Foucault usvækket. Vi gjorde videnskaben til en af de vigtige faktorer i perioden og henviste det politiske til en 4. og 5. plads. Vores historie om monstrøse mennesker, hysterikeren, de perverse og mennesket, der blev en abekat, fik en anmelder (ansat i gymnasieskolen) til at 
skrive, at han ikke befandt sig særlig godt med alle disse ubehagelige mennesker. Universitetshistorikerne, som anmeldte bogen, var mildest talt ikke begejstret for vores behandling af den 'rigtige' politiske historie. Jeg er stadig overbevist om, at videnskaben var et nyt og vigtigt træk ved det moderne, og at det var vigtigt at få det politiske bredt ud. Videnskaben er også en historisk konstruktion og et politisk felt.

Jeg tænkte derefter, at tiden måtte være inde til At glemme Foucault, som var titlen på Jean Baudrillards bog fra 1982, men da jeg efter min disputats i 1993 skulle finde på et nyt projekt, blev det et gammelt ønske om at se på Mødrehjælpens historie, som jeg tog op. Materialet nærmest råbte på Foucault. Her var tale om en institution, som skulle forvaltes af uddannede sociale hjælpere (nutidens socialrådgivere), altså eksperter, og hvor der foregik en form for bekendelse. ${ }^{1}$

\section{DET POLITISKE ÆGTESKAB}

Mit næste store projekt tog i første omgang en drejning bort fra Foucault. Jeg gik fra de illegitime, ugifte mødre og uægte børn til det legitime xgteskab. "Det nordiske xgteskabsprojekt", som startede i 1996, var mere aktørorienteret. ${ }^{2}$ Med i gruppen var desuden Kari Melby, Anu Pylkkänen og Christina Carlsson Wetterberg. Hovedproduktet var bogen: Inte ett ord om kärlek. Äktenskap och politik $i$ Norden ca. 1850-1930, som udkom i 2006. Hvordan havde læger, feminister og politikere bidraget til xgteskabsreformerne, som vi fik i alle de nordiske lande i begyndelsen af det 20. århundrede? Ægteskabsprojektet var jeg overhovedet ikke interesseret i at gå ind i, men lovede at komme til et planlægningsmøde i Helsingfors i 1996. Noget mere dødsygt end rgteskabet skulle man i min daværende optik lede længe efter. Jeg har som så mange andre grinet af xgteskabslovene i 1920'erne, som indførte ligestilling, men samtidig fastholdt kvinder som husmødre, der havde ret til lommepenge! Min gode og desværre nu afdøde kollega retshistorikeren Anu Pylkkänen havde mere sans for, hvad jeg kunne bidrage med, end jeg selv havde, nemlig videnskabens italesættelse af kvindelighed og biopolitikken.

Det blev det mest givende forskningssamarbejde, som jeg har været med i, og det varede ca. 10 år. Foucault kom med på bagsmækken igen og gav projektet en drejning, der skærpede det politiske aspekt ved xgteskabet. Som udgangspunkt skildrede vi den politiske proces, hvor især jurister og kvindeaktivister var aktive. Men det gik hurtigt op for os, at kirken var blevet sendt ud på et sidespor og erstattet af en ny ekspertgruppe: lægerne. Det var i overensstemmelse med Foucaults teorier, at videnskaben kom til at spille en vigtig rolle i udformningen af rgteskabslovgivningen i begyndelsen af det 20. århundrede. En lovgivning, der næsten blev enslydende i de nordiske lande. Disse familiereformer var udtryk for en liberalisering, demokratisering og modernisering, som blev gennemført 50 år før i Norden end i resten af Europa. Vores konklusion i bogen Inte ett ord om kärlek var, at den nordiske xgteskabsmodel var unik i grundlaget for de nordiske velfærdssamfund ved at være sekulær, gøre op med et patriarkalsk fundament, lægge vægt på individualisme og ligestilling, men også ved at give staten mere magt over medborgerne.

Ægteskabsreformerne i de nordiske lande, som blev gennemført i perioden 1909 til 1919, var en vigtig forudsætning for den senere socialpolitiske udvikling og for velfærdsstaten. Ægteskabsinstitutionen blev moderniseret og kvinders individuelle rettigheder udvidet. For det første blev betingelserne for indgåelse af xgteskab xndret, idet nye medicinske hindringer blev introduceret, og kvinders minimumsalder blev hævet til 18 år. Kvinder skulle være modne, inden de indgik xgteskab. For det andet blev skilsmisse liberaliseret, og skilsmisse uden skyld men baseret på varig uoverens- 
stemmelse blev accepteret. For det tredje blev der indført ligestilling mellem parterne, som implicit medførte en ret til lønarbejde for så vidt, at mænd ikke kunne forbyde deres koner at have et udeerhverv. Kvinder fik desuden på dette tidspunkt del $\mathrm{i}$ forældremyndigheden.

Der blev endvidere indført gensidig forsørgerpligt. Selv om denne kunne opfyldes gennem arbejde i hjemmet, og selv om mænd ikke kunne pålægges husarbejde, var det ikke uvæsentligt, at kvinder fik en slags forsørgerstatus, dvs. blev en form for medforsørgere. Den danske lov vedrørende retsstilling mellem parterne slog ligestillings- og gensidighedsprincippet fast i første paragraf, som lød: "Mand og Hustru skal være hinanden til Støtte. De skal i Fællesskab varetage Familiens Tarv" (Melby et al.: 159ff). Både manden og kvinden blev forpligtet på familien og dens tarv, som oversættes med velfærd på engelsk.

Med ægteskabsreformerne blev familien og det private et område for politik. Mens det reproduktive tidligere var blevet set som en naturlig proces og familien som noget privat, begyndte dette at forandre sig i begyndelsen af 1900-tallet. Reproduktion blev langsomt genstand for politik, og staten tog de første skridt til at intervenere i familien. Dette slog eksplicit igennem i 1930'erne, hvor synet på fattigdom ændrede karakter og blev opfattet snarere som et socialt end et politisk problem. Dermed blev velfærdsbegrebet udvidet. Mens sociallovgivningen $\mathrm{i}$ et historisk perspektiv havde været rettet udelukkende mod den fattigste del af befolkningen, blev hele befolkningen efterhånden målgruppen. Da social- og sundhedslovgivningen blev knyttet sammen, blev det forebyggende arbejde vigtigt. Her kom familien, kvinden og kønnet til at spille en stor rolle. Og kvinderne var med xgteskabslovens ligestillingsprincip blevet værdige aktører.

Ikke kun blev velfærdsbegrebet udvidet. Også holdningen til statsinterventionisme ændrede sig. Helt frem til 1930'erne var der et vist forbehold over for statslige indgreb også i kvindebevægelsen. Der blev værnet om familiens privathed. I 1930'erne blev holdningen til statsintervention mere positiv inden for områder som svangerskab, fødsel og spædbarnspleje. Ændringen skete på samme tid som socialpolitik og sundhedspolitik blev knyttet sammen, og der blev lagt vægt på forebyggelse. Socialpolitikken blev videnskabeliggjort. Det lykkedes at få omformuleret en befolkningspolitik til en mere demokratisk socialpolitik. Samtidig var påbuddet om reproduktion ganske fremtrædende. Begge dele var tydelig hos K.K. Steincke, som var en dansk socialdemokratisk politiker (Melby et al.: $275 \mathrm{ff}$ ). For Steincke var en familie med to ansvarlige personer vigtig, og staten skulle begunstige "den æegteskabelige Frugtsommelighed". To-barnsfamilien var en trussel (ibid.: 281). Hensynet til forplantningen medførte dog også negativ eugenik, det ville ifølge Steincke sige, at man skulle hindre 'undermålerne' i at formere sig. Det var en forudsætning for at udvide socialpolitikken. I Sverige forsøgte de svenske socialdemokratiske politikere Alva og Gunnar Myrdal med udgangspunkt i befolkningsspørgsmålet at udforme en mere moderne udgave af socialpolitik. Specielt i 1920'erne og 1930'erne indgik politikerne en alliance med videnskaben som institution, en alliance som fik stor betydning for velfærdsstaten. Politikken byggede på frivillighed, men individuel frihed og udfoldelse blev underordnet en 'reproduktionens jernlov'. Alva og Gunnar Myrdal var parate til at acceptere heteroseksualitet i den betydning, at seksualitet var adskilt fra avl og reproduktion, men de stillede kernefamilie og børneproduktion op som en norm. Social ansvarlighed stod over for individualisme, men ingen tvivl om, at kvinder og mænds vigtigste opgave var at indgå xgteskab og avle børn. Denne nye politik vedrørende reproduktion og xgteskabsreform var et eksempel på Foucaults biopolitik. Den vedrører kroppen i bred forstand, herunder re- 
gulering af befolkningen og disciplineringen af legemet.

Der blev etableret en tæt sammenhæng mellem forplantning, befolkning og reproduktion og mellem befolkningspolitik, socialpolitik og racehygiejne. Befolkningsspørgsmålet kaster lys over relationen mellem ægteskabsreformer og velfærdsstaten. Racehygiejnen begyndte at dukke op i Norden omkring 1910 samtidig med, at det nordiske samarbejde om familieretten påbegyndtes. Lægerne og kvinderne blev de to grupper, som kommissionen inddrog som eksperter. Det var især i spørgsmålet om xgteskabshindringer, at den lægelige ekspertise blev benyttet. Der skete dog ingen radikalisering på dette område. Også tidligere havde forskellige handikap, herunder åndssvaghed, været betragtet som en xgteskabshindring. Men argumentationen ændrede karakter og blev nu videnskabelig. Eksplicit slog racehygiejnen således ikke stærkt igennem i ægteskabslovgivningen, dog stærkere i Sverige og Finland end i Danmark og Norge. Dette kan hænge sammen med, at der i en lang periode var en vis tøven over for, om racehygiejnens resultater nu var tilstrækkeligt videnskabeligt begrundet. Efterhånden blev usikkerheden mindre. Påfaldende er det, at det blev den finske ægteskabslov, der først blev vedtaget i 1929, som var mest radikale, og som medtog f.eks. døvstumhed som xgteskabshindring. I 1938 kom der også en lovændring i Danmark, som skærpede ægteskabshindringerne og medtog f.eks. epilepsi og kronisk alkoholisme samtidig med, at der kunne stilles krav om sterilisation som forudsætning for ægteskab i visse tilfælde. Som årene gik, blev tilliden til den nye videnskab øget, og i 1930'erne indførtes steriliseringslove i de nordiske lande.

De mere eksplicitte racehygiejniske principper var ikke fremtrædende, men implicit kan der spores befolkningspolitiske hensyn. Allerede i de indledende bemærkninger til Familieretskommissionens betænkning fra 1913 blev der i det danske lovudkast nævnt eksplicit, at videnskaben havde leveret et nyt grundlag for at "værne om ægtefællerne og deres afkoms sundhed", mens det svenske udover beskyttelse af kommende slægter også nævnte en forbedring af den menneskelige race. I Norge mente man derimod ikke, at racehygiejnens resultater var så anerkendte, at de kunne lægges til grund for lovgivning. I den danske lov blev der med henvisning til videnskaben opstillet et overordnet hensyn, som satte grænser for "individernes frihed", som ellers havde høj prioritet i reformerne. Dette hensyn viste om noget samfundets ønske om at regulere og kontrollere. Der var tale om et forsøg på at få kontrol med familien og befolkningen.

\section{FRA ALLIANCE- TIL}

\section{SEKSUALITETSINSTALLATIONEN}

Michel Foucault har bidraget til en analyse af xgteskabet i Seksualitetens historie bind I ved at rejse spørgsmålet om, hvorvidt ægteskabet har mistet betydning i det moderne samfund til fordel for en ny installation, som han benævner seksualitetsinstallationen. Alliancesystemet er opbygget omkring et regelsystem, som definerer det tilladte og det forbudte, det foreskrevne og det utilladelige. Seksualitetsinstallationen er underlagt andre og mere diffuse magtteknikker, hvor igennem populationerne kontrolleres, og dens vigtigste elementer er det kvindelige legeme, barnets seksualitet, fødselskontrol, herunder reguleringen af befolkningen og specifikation af de perverse (se især kap. IV).

Foucault er ikke særlig interesseret i loven, men i diskurser, der vedrører barnets legeme, kvindekønnet og den børnebegrænsende praksis. Seksualiteten er bindeled mellem mænd og kvinder, mellem forældre og afkom, mellem forvaltning og befolkning. Reproduktion, heteroseksualitet og ægteskabelig legitimitet kom i centrum. Socialiseringen til forplantningsadfærden består dels af en økonomisk socialisering formidlet af de sociale eller finansielle forholdsregler, som tilskynder eller hæmmer parrenes seksualitet; dels af 
politisk socialisering, hvorved parrene gøres ansvarlige over for hele samfundslegemet, og endelig en medicinsk socialisering. Ansvarlighed over for samfundet omfattede både de økonomiske forhold og hensynet til forplantningen. Dermed blev befolkningen og familien inddraget i det politiske felt.

Reproduktion skulle styres ved at gøre befolkning, sundhed og seksualitet til et videnskabeligt, medicinsk og politisk objekt. Både begrebet 'biopolitik' og dominansbegrebet 'governmentality' eller på dansk guvernementalitet, der henviser til den omfattende regulering, som finder sted i det moderne samfund gennem videnskabelige diskurser og heraf afledte teknikker, kan bidrage til at forny analyserne af familie og familiepolitik, herunder socialpolitik og velfærd ved at inddrage det private. Den moderne stat er ikke en stat, som er ligeglad med sine borgere, men forsøger at integrere individerne. Individerne skal ikke føres mod frelse i det næste liv, men tilfredsstilles her og nu ved hjælp af f.eks. sundhedspolitik, socialpolitik og velfærd. Magten udøves somme tider af private foretagender f.eks. filantropiske organisationer, men også af familien. Det var viden og kundskab, der gav magt. Magtens mål var regulering af befolkningen og disciplineringen af individet. Der blev lagt vægt på kontrol og den normative regulering. Et Foucault-inspireret forskningsperspektiv leder til en interesse for helt andre spørgsmål og andre sagsområder inden for velfærdsstatshistorie end arbejdsmarked og produktion. Velfærdsstatens institutioner handler ikke bare om rettigheder og uafhængighed af markedet, men også om normer, der indeholder bestemte opfattelser af kvinders og mænds plads i samfundet og om deres opgaver.

\section{REPRODUKTION SOM}

FORTOLKNINGSRAMME

FOR VELFÆRDSSAMFUNDET

At reproduktion, som dét der bestemmer befolkningens størrelse og afkommets kvalitet, står centralt i de moderne velfærdssam- fund, har Kari Melby og jeg udfoldet i en artikel: "Reproduksjon som fortolkningsramme for de nordiske velferdsstater: Foucault møter Giddens” (2009). Vi hævder, at reproduktionspolitik og statsintervention i det private liv både var udtryk for biopolitik med fokus på regulering af befolkningen og disciplineringen af kroppen og for individualisering - også af kvinder. Gifte kvinder blev inkluderet i medborgerskabet, ved at reproduktion blev genstand for politik. Denne politisering af reproduktion var muliggjort af sekularisering, videnskabeliggørelse og statslig intervention. Det nye ved reguleringen var, at der ikke længere var tale om forbud og straf, men om afkriminalisering og liberalisering. En offentlig bekymring for befolkningen kan både udløse velfærdstiltag for at forbedre forholdene for familier, herunder kvinder og børn og motivere disciplinering og kontrol af reproduktionen.

På den ene side blev ægteskabslovene et redskab til at kontrollere befolkningen og reproduktionen, såvel kvantitativt som kvalitativt. På den anden side blev de gifte kvinder ligestillet i langt højere grad end i tidligere lovgivning. Kvinder blev politiske subjekter på en måde, som de ikke havde været før, men som vi har set, opnåede kvinder socialt medborgerskab som hustruer og mødre, og deres medborgerskab var begrænset af, at de var tilknyttet privatsfæren.

I projektet "Det nordiske ægteskab i europxisk perspektiv. Modernisering og kønskonstruktion" anlægger vi et dobbeltperspektiv, som giver rum for forandring, udvikling og et aktørperspektiv, og fastholder samtidig en normativitets- og magtkritik. Den mest udbredte Foucault-læsning i dag er i forhold til neoliberalismen, hvor vægten ligger på en allestedsnærværende disciplinering af sociale relationer, på magtregimer og ledelsesteknikker og på, hvordan mennesker leder sig selv og ledes af andre. Dette aspekt er vigtigt, men vi har også lagt vægt på demokratisering. Foucault har 
nemlig også en anden side, som var den forskning i køn og seksualitet oprindelig tog afsæt i, nemlig hans dekonstruerende historicitetsanalyser. Han tog et opgør med naturaliseringen af en række fænomener som f.eks. galskab og seksualitet og henviste til forandring, til at noget er historisk og ikke naturlig. Foucaults perspektiv er ikke kun disciplinering. Med sine genealogier viser han også til forandring. Derfor lod Kari Melby og jeg Foucault møde Giddens i vores bestræbelse på at udvikle reproduktion som fortolkningsramme for de nordiske velfærdsstater.

\section{INTIMT MEDBORGERSKAB}

Anthony Giddens tager udgangspunkt i Foucaults ‘føjelige' kroppe, perversioner og seksualitet som social konstruktion, men han kritiserer ham for ikke at sige noget om seksualitetens forbindelse med den romantiske kærlighed; Et fænomen som er nært forbundet med ændringer i familien. Selv om hverken kærlighed eller følelser spillede nogen rolle i ægteskabsreformerne i begyndelsen af det 20. århundrede, foregik der en følelsesmæssig revolution. Seksualitet og reproduktion blev adskilt og 'heteroseksualiteten' i betydningen ikke-reproduktiv seksualitet blev 'opfundet'. De private relationer har ændret sig, og den private sfære er blevet demokratiseret. En udvikling, der peger i retning af et intimt/seksuelt medborgerskab. Med Giddens får vi et bedre blik for forandring og for aktørerne.

Medborgerskabsbegrebet i sin klassiske udformning, som omfatter civile, politiske og sociale rettigheder, kan kritiseres for at have lagt vægt på det offentlige og udelukket forhold, som er blevet associeret med det private. Flere forskere (bl.a. Ken Plummer, Jeffrey Weeks, Diane Richardson) har introduceret et begreb om seksuelt eller intimt medborgerskab, som tager udgangspunkt i kroppen og nedbryder grænserne mellem det private og det offentlige. Intimt eller seksuelt medborgerskab kan ses som en videreudvikling af Giddens analyse af intimiteten, som betegner demokratisering af relationer i den private sfære. Samtidig er krav om ligestilling og rettigheder rejst af mange forskellige grupper, og der er ved at udvikle sig et medborgerskabsbegreb, som tager udgangspunkt i det private. Andre taler om kropslig og reproduktiv medborgerskab. Et nyligt afsluttet EU projekt "Femcit: Gendered Citizenship in Multicultural Europe: impact of contemporary women's movement" opererer med seks dimensioner af medborgerskabet. ${ }^{3}$

Ruth Lister, som i høj grad har bidraget til at kønne medborgerskabet, argumenterer i kapitlet "From the Intimate to the Global: Reflections on Gendered Citizenship" fra bogen The Limits of Gendered Citizenship. Contexts and Complexities (2009) overbevisende for, at vi skal udvikle teorier, der omfatter både intimt medborgerskab og globalt medborgerskab. Jeg ser således to bevægelser: fra samfundet og ind i familien, det intime og fra den enkelt stat og ud i verden, det globale.

Intimiteten i det 'moderne' i stil med Anthony Giddens' individualiseringstese sammen med den romantiske ide om absolut kærlighed var også fremtrædende i Ulrich Beck og Elisabeth Beck-Gernsheims bog Das ganz normale Chaos der Liebe (1990, bogen er oversat til engelsk). Senest har de i 2013 udgivet bogen Fernliebe. Lebensformen im globaler Zeitlalter. I den nye bog er fokus på fjerne kærlighedsrelationer, på kærlighedens globale kaos med bi-nationale par, ægteskabs- og arbejdsmigranter med rugemødre og med Skype-understøttede kærlighedsforhold, som de kalder det. Den nationale familie er blevet til en verdensfamilie, og her møder mennesker konkrete forskelle, som måske kan gøre dem og os alle bedre egnet til at leve $\mathrm{i}$ en verden med forskelligheder. Problemer i disse relationer er der mange af, men der er også muligheder for at lære at leve med forskelligheder. Meget smukt men også meget idealistisk. Kan man tro på, at man i de nye kærlig- 
heds- og familieformer kan finde ud af at leve henover grænserne?

\section{AfsLUTNING}

Mens vi arbejdede med ægteskabet blev dette et mere og mere centralt emne og med udgangspunkt i en konference publicerede vi endnu en bog, nemlig Det politiska Äktenskapet. 400 àrs historia om familj och reproduktion (2010), som jeg redigerede sammen med Hanne Sanders. I forhold til de tidligere publikationer var målet at afdække historiens lange linjer fra 1600-tallet og frem til nutiden samt at anlægge et tværkulturelt perspektiv.

Der er flere muligheder end nogensinde for at udvikle teorier om ægteskab og familie. Foucault er vigtig, men lad være med at tro, at han har svar på alt. Vær utro imod ham på samme måde, som han var imod Nietzsche, som han brugte efter eget forgodtbefindende. $\mathrm{Og}$ så skal vi måske lave genealogier i stedet for at læse så meget teori. Jeg vil gerne fremhæve det svar, som Foucault kom med til den amerikanske forsker Jana Sawiski, da hun fortalte ham, at hun skrev afhandling om ham: "Skriv genealogier". Denne opfordring er hermed givet videre.

\section{Noter}

1. Se publikationer på:

http://koensforskning.ku.dk/forskning/karlig-

hedogseksualitet/

2. Se publikationer på:

http://koensforskning.ku.dk/forskning/agte-

skab/;

http://koensforskning.ku.dk/forskning/nordw-

ell/.

3 Se mere på: http://www.femcit.org/

\section{LITTERATUR}

- Baudrillard, Jean (1982): At glemme Foucault. Rhodos, København

- Beck, Ulrich \& Beck-Gernsheim Elisabeth

(1990): Das ganz normale Chaos der Liebe. Forlag by. Suhrkamp, Berlin

- Beck, Ulrich \& Beck-Gernsheim Elisabeth (2013): Fernliebe. Lebensformen im globaler Zeitlalter. Suhrmap, Berlin

- Duschinsky, Robbie \& Rocha, Leon Antonio (eds.) (2012): Foucault, the Family and Politics. Palgrave Macmillan, London

- Lister, Ruth (2009): From the Intimate to the Global: Reflections on Gendered Citizenship, i Elzbieta Oleksy et al.: The Limits of Gendered Citizenship. Contexts and Complexities. Routledge, New York

- Lützen, Karin \& Rosenbeck, Bente (1991): Den moderne tid, i Søren Mørch (red.): Det Europaiske Hus. Forlag, by. Gyldendal, København

- Matthiessens, P.C. (1970): Some Aspects of the Demographic Transition in Denmark. Disputats,

København

- Melby, Kari, Pylkkänen, Rosenbeck, Bente, Wetterberg, Christina Carlsson (2006): Inte ett ord om kärlek. Äktenskap och politik $i$ Norden ca. 1850-

1930. Makadam Förlag, Stockholm

- Melby, Kari og Rosenbeck, Bente (2009): Reproduksjon som fortolkningsramme for de nordiske velferdsstater: Foucault møter Giddens, i Tidsskrift for kjønnsforskning, 2009/1

- Rosenbeck, Bente (1987): Kvindekøn. Den moderne kvindeligheds historie 1880-1980. Gyldendal, København

- Rosenbeck, Bente (1992): Kroppens politik. Museum Tusculanum, København

- Rosenbeck, Bente og Sanders, Hanne (red.) (2010): Det politiska Äktenskapet. 400 års historia om familj och reproduktion (2010). Makadam Förlag, Stockholm 